\title{
Zinc Supplementation Forms Influenced Zinc Absorption and Accumulation in Piglets
}

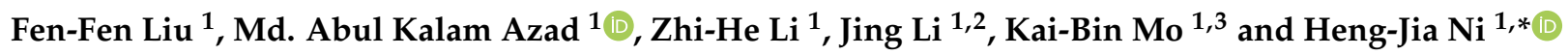 \\ 1 Key Laboratory of Agro-Ecological Processes in Subtropical Region, Hunan Provincial Key Laboratory of \\ Animal Nutritional Physiology and Metabolic Process, Hunan Research Center of Livestock and Poultry \\ Sciences, South Central Experimental Station of Animal Nutrition and Feed Science in the Ministry of \\ Agriculture, Institute of Subtropical Agriculture, Chinese Academy of Sciences, Changsha 410125, China; \\ liufenfen0327@163.com (F.-F.L.); azadmak@isa.ac.cn (M.A.K.A.); 17347124127@189.cn (Z.-H.L.); \\ lijing16099@163.com (J.L.); mokaibin2008@outlook.com (K.-B.M.) \\ 2 Department of Animal Science, Hunan Agriculture University, Changsha 410125, China \\ 3 College of Veterinary Medicine, South China Agricultural University, Guangzhou 510642, China \\ * Correspondence: nihengjia@isa.ac.cn
}

check for updates

Citation: Liu, F.-F.; Azad, M.A.K.; Li, Z.-H.; Li, J.; Mo, K.-B.; Ni, H.-J. Zinc Supplementation Forms Influenced Zinc Absorption and Accumulation in Piglets. Animals 2021, 11, 36. https://dx.doi.org/10.3390/ ani11010036

Received: 7 December 2020 Accepted: 24 December 2020 Published: 27 December 2020

Publisher's Note: MDPI stays neutral with regard to jurisdictional claims in published maps and institutional affiliations.

Copyright: (c) 2020 by the authors. Licensee MDPI, Basel, Switzerland. This article is an open access article distributed under the terms and conditions of the Creative Commons Attribution (CC BY) license (https: / / creativecommons.org / licenses/by/4.0/).
Simple Summary: High levels of inorganic $\mathrm{Zn}$ were supplemented to meet the nutritional requirements of $\mathrm{Zn}$ in piglets, which results in the development of intestinal microbial resistance and environmental pollution. Previous research indicated that organic $\mathrm{Zn}$ sources had higher bioavailability than inorganic $\mathrm{Zn}$. There is limited information on the comparison of dietary $\mathrm{Zn}$ source dissolved in water with other $\mathrm{Zn}$ supplementation forms in piglets. Therefore, the present study was designed to compare the effects of three $\mathrm{Zn}$ supplementation forms ( $\mathrm{Zn}-\mathrm{Met}$ in the feed, $\mathrm{ZnSO}_{4}$ in the feed, and $\mathrm{ZnSO}_{4}$ dissolved in drinking water) on growth performance, $\mathrm{Zn}$ accumulation, activities of $\mathrm{Zn}$-containing enzymes, expression of MT, and Zn transporters in piglets. In conclusion, $\mathrm{Zn}$-Met and $\mathrm{ZnSO}_{4}$ dissolved in drinking water had higher bioavailability in piglets.

Abstract: The study aimed at determining the effect of different zinc (Zn) supplementation forms on $\mathrm{Zn}$ accumulation, activities of $\mathrm{Zn}$-containing enzymes, gene expression of metallothionein (MT), and $\mathrm{Zn}$ transporters in piglets. Eighteen piglets were randomly divided into three groups: (a) a basal diet supplemented with $150 \mathrm{mg} / \mathrm{kg}$ Zn from Zn methionine (Zn-Met) in the feed (Zn-Met group), (b) a basal diet supplemented with $150 \mathrm{mg} / \mathrm{kg} \mathrm{Zn}$ from $\mathrm{Zn}$ sulfate $\left(\mathrm{ZnSO}_{4}\right)$ in the feed $\left(\mathrm{ZnSO}_{4}\right.$, feed group), and (c) a basal diet supplemented with the same dose of $\mathrm{Zn}$ as in $\mathrm{ZnSO} 4$,feed group but in water $\left(\mathrm{ZnSO}_{4}\right.$, water group). The results showed that $\mathrm{Zn}-$ Met added in feed and $\mathrm{ZnSO}_{4}$ dissolved in drinking water significantly improved $(p<0.05)$ the $\mathrm{Zn}$ concentration in liver and jejunum and the apparent digestibility of $\mathrm{Zn}$ in comparison with the $\mathrm{ZnSO}_{4}$ added in feed. In addition, dietary Zn supplementation as Zn-Met significantly increased $(p<0.05)$ the activity of alkaline phosphatase $(\mathrm{AKP})$ in the jejunum of piglets in comparison with the $\mathrm{ZnSO}_{4}$, feed group. Furthermore, the $\mathrm{Zn}$-Met and $\mathrm{ZnSO}_{4}$, water groups showed an improved total superoxide dismutase activity (T-SOD) in the ileum as compared to the $\mathrm{ZnSO}_{4}$, feed group. Meanwhile, the qPCR and western blot results showed that $\mathrm{Zn}-\mathrm{Met}$ and $\mathrm{ZnSO}_{4}$ dissolved in drinking water increased the expression of MT in the jejunum in comparison with the $\mathrm{ZnSO}_{4}$ added in the piglets' feed. However, different $\mathrm{Zn}$ supplementation forms had no effect on the mRNA expressions of Zip4 and ZnT1 transporters. In conclusion, Zn-Met added in feed and $\mathrm{ZnSO}_{4}$ dissolved in drinking water had higher bioavailability in piglets.

Keywords: zinc; zinc methionine; metallothionein; mineral concentration; pig

\section{Introduction}

Zinc is one of the most essential trace minerals elements for animals, owing to its key role as an important component involved in forming numerous metalloenzymes and transcription factors [1]. Zn deficiency, usually caused by inadequate dietary Zn intake, 
affects growth, brain functions, and immune activity [2-4]. In pig production, the widely used forms of $\mathrm{Zn}$ are inorganic $\left(\mathrm{ZnSO}_{4}, \mathrm{ZnO}\right)$ because of their low cost and commercial preference. However, excessive feeding of high levels of inorganic $\mathrm{Zn}$ to piglets can stimulate resistance in the gut microbiota and may also result in a substantial excretion of Zn into the environment $[5,6]$.

Research evidence has indicated that organic $\mathrm{Zn}$ sources is recommended widely in animals because of their higher bioavailability than inorganic Zn [7,8]. Xie et al. [9] reported that piglets with body weight of $11 \mathrm{~kg}$ fed diet supplemented with a lower dose of $\mathrm{Zn}$-Met replacing $100 \mathrm{mg} / \mathrm{kg} \mathrm{ZnSO} 4$ had no negative effects on nutrient digestibility, growth performance, and serum metabolites, and indeed, supplementing $50 \mathrm{mg} \mathrm{ZnSO}_{4}$ plus $25 \mathrm{mg} \mathrm{Zn}$-Met to piglets exerted the beneficial effects of Zn digestibility and immune functions. Furthermore, Li et al. [10] found that in 38 weeks old laying hens dietary Zn-Met had beneficial effect on $\mathrm{Zn}$ accumulation in tissues, intestinal morphology, and the mRNA expression of metallothionein (MT) in the intestinal as compared to $\mathrm{ZnSO}_{4}$ supplementation in the diet. However, there is limited information on the comparison of dietary $\mathrm{Zn}$ source dissolved in water with other $\mathrm{Zn}$ supplementation forms in piglets. Therefore, based on these studies of foregoing, it was hypothesized that different $\mathrm{Zn}$ supplementation forms might influence effect growth performance, $\mathrm{Zn}$ accumulation, activities of $\mathrm{Zn}$-containing enzymes, and the expression of MT and Zn transporters in piglets.

\section{Materials and Methods}

\subsection{Animals, Diets and Experimental Design}

The experimental design and procedures used in the present study were approved by the Animal Care and Use Committee of the Institute of Subtropical Agriculture, Chinese Academy of Sciences (IACUC \# 201302).

Eighteen healthy male piglets (Duroc $\times$ (Danish Landrace $x$ Yorkshire), 2nd and 3rd parities) with an average body weight of $14.47 \pm 0.51 \mathrm{~kg}$ were randomly assigned to three dietary treatments with 6 animals each. The experiment lasts for 21 days. The treatment groups were follows: (a) Zn-Met group; a basal diet supplemented with $150 \mathrm{mg} / \mathrm{kg} \mathrm{Zn}$ from $\mathrm{Zn}$-Met in the feed, (b) $\mathrm{ZnSO}_{4}$, feed group; a basal diet supplemented with $150 \mathrm{mg} / \mathrm{kg}$ $\mathrm{Zn}$ from $\mathrm{ZnSO}_{4}$ in the feed, and (c) $\mathrm{ZnSO}_{4}$, water group; a basal diet supplemented with the same dose of $\mathrm{ZnSO}_{4}$ dissolved in water as $\mathrm{ZnSO}_{4}$, feed group. The same dose $\mathrm{Zn}$ supplementation with three different patterns was based on limiting feed and water which containing $\mathrm{ZnSO}_{4}$. The drinking water method of piglets in $\mathrm{ZnSO}_{4}$, water group was according the method described by Kaewtapee et al. [11]. Briefly, the loss of water in the home-made bottles which contains $\mathrm{ZnSO}_{4}$ was collected by a tray under the pen throughout the experimental period. The daily feed intake and $\mathrm{ZnSO} 4$ in drinking water intake are shown in Table S1. The methionine content in the diets was maintained for all groups by adding methionine in the feed (i.e., for $\mathrm{ZnSO}_{4}$, feed and $\mathrm{ZnSO}_{4}$, water groups). Zinc sulfate $\left(\mathrm{ZnSO}_{4}\right.$; Aladdin Biochemical Reagent Company, Shanghai, China) and Zn-Met (Tanke Group, Guangzhou, China) were pre-added in the premix or dissolved in drinking water to maintain their concentrations in the different dietary treatments. The composition nutrient levels of the basal diet met the National Research Council (2012) nutrient recommendation, as shown in Table 1.

\subsection{Housing and Sample Collection}

The piglets were housed in metabolic cages ( $1.5 \mathrm{~m}$ length $\times 0.8 \mathrm{~m}$ width) individually, and the room temperature was maintained at $25^{\circ} \mathrm{C}$. At the end of the experiment, $12 \mathrm{~h}$ after the last feeding, the piglets were weighed and sacrificed by electric shock $(120 \mathrm{~V}, 200 \mathrm{~Hz})$ for the sample collection. Liver and intestinal segments (the middle section of duodenum, the middle section of jejunum, the middle section of ileum) were collected. The intestine segments and liver were rinsed with physiological saline and quickly cut into lengths of 2 to $3 \mathrm{~cm}$, then these segments were frozen in liquid nitrogen and stored at $-80{ }^{\circ} \mathrm{C}$ for further analysis. One portion of the duodenum, jejunum and ileum, and the liver samples 
were cut into pieces of approximately $20 \mathrm{~g}$ per sample and were then stored at $-20{ }^{\circ} \mathrm{C}$ for further $\mathrm{Zn}, \mathrm{Fe}$, and $\mathrm{Cu}$ analysis.

Table 1. Composition of basal diet (as-fed basis) for piglets.

\begin{tabular}{|c|c|c|c|}
\hline Ingredient & Content $(\%)$ & Analyzed Value & \\
\hline Corn & 63.80 & Digestible energy (MJ. kg ${ }^{-1}$ ) & 14.05 \\
\hline Soybean meal & 19.80 & Crude Protein $(\%)$ & 18.27 \\
\hline Whey powder & 4.30 & Crude fat $(\%)$ & 4.20 \\
\hline Fish meal & 9.00 & Crude fiber (\%) & 2.55 \\
\hline Soybean oil & 0.80 & Lysine (\%) & 1.37 \\
\hline Lysine & 0.38 & Methionine + Cysteine (\%) & 0.76 \\
\hline Threonine & 0.09 & Threonine (\%) & 0.88 \\
\hline Tryptophan & 0.01 & Calcium (\%) & 0.80 \\
\hline Limestone & 0.52 & Phosphorus (\%) & 0.64 \\
\hline Salt & 0.30 & Zinc $(\mathrm{mg} / \mathrm{kg})$ & 70.46 \\
\hline $1 \%$ premix $^{1}$ & 1.00 & Copper (mg/kg) & 47.47 \\
\hline Total & 100.00 & Iron $(\mathrm{mg} / \mathrm{kg})$ & 195.09 \\
\hline
\end{tabular}

${ }^{1}$ Premix supplied per kilogram of diet: vitamin $\mathrm{A}_{1}, 11809.4 \mathrm{IU}$; vitamin $\mathrm{D}_{3}, 5480 \mathrm{IU}$; vitamin $\mathrm{E}, 43.84 \mathrm{IU}$; vitamin $\mathrm{K}_{3}, 10.96 \mathrm{mg}$; vitamin $\mathrm{B}_{2}, 13.70 \mathrm{mg}$; vitamin $\mathrm{B}_{1}, 5.48 \mathrm{mg}$; vitamin $\mathrm{B}_{6}, 6.58 \mathrm{mg}$; vitamin $\mathrm{B}_{12}, 0.05 \mathrm{mg}$; vitamin $\mathrm{C}$, $109.60 \mathrm{mg}$; choline $1644 \mathrm{mg}$; salt, $2959 \mathrm{mg}$; sugar, $7891 \mathrm{mg}$; niacin/niacinamide, $54.80 \mathrm{mg}$; folic acid, $2.74 \mathrm{mg}$; biotin, $0.33 \mathrm{mg}$; lysine, $5477 \mathrm{mg}$; methionine, $1754 \mathrm{mg}$; threonine, $2192 \mathrm{mg}$; $\mathrm{Cu}$ as $\mathrm{CuSO}_{4} \cdot 5 \mathrm{H}_{2} \mathrm{O}, 38.22 \mathrm{mg}$; $\mathrm{Fe}$ as ferrous bisglycinate chelate, $112 \mathrm{mg}$; I as KI, $0.19 \mathrm{mg}$; $\mathrm{Mn}$ as $\mathrm{MnSO}_{4} \cdot \mathrm{H}_{2} \mathrm{O}, 71.25 \mathrm{mg}$; Se as $\mathrm{Na}_{2} \mathrm{SeO}_{3}, 0.27 \mathrm{mg}$; $\mathrm{Co}$ as $\mathrm{CoCl}_{2}, 0.11 \mathrm{mg}$.

\subsection{Chemical Composition of Feed Analysis}

Laboratory analyses were carried out on feed samples using the standard AOAC (1995) procedures to determine digestible energy, crude protein, crude fat, and crude fiber content [12]. Lysine, methionine plus cysteine, and threonine were determined using the method of Miaomiao et al. [13].

\subsection{Mineral Concentration Analysis}

The mineral concentration of each sample was measured according to the method described by Cheng et al. [14]. Approximately $2 \mathrm{~g}$ of each fresh sample was weighed in triplicate and mixed with $10 \mathrm{~mL}$ of nitric acid and perchloric acid mixture $(4: 1, v / v)$. Then, the samples were kept for $12 \mathrm{~h}$ at room temperature and then digested to obtain clear digested solutions. The mixture was then heated to $80^{\circ} \mathrm{C}$ for $1 \mathrm{~h}$, followed by $120^{\circ} \mathrm{C}$ for $1 \mathrm{~h}, 180{ }^{\circ} \mathrm{C}$ for $1 \mathrm{~h}, 220^{\circ} \mathrm{C}$ for $1 \mathrm{~h}$, and then maintained at $260{ }^{\circ} \mathrm{C}$ until dried to ash. The dried samples were suspended in $10 \mathrm{~mL} 1 \%$ nitric acid and filtered before analysis. The final solutions were analyzed for mineral concentrations using an Inductive Coupled Plasma Emission Spectrometer (ICP-720ES; Agilent, Palo Alto, CA, USA). The mineral concentrations were expressed as micrograms of mineral per gram of liver and intestinal segments.

\subsection{Apparent Digestibility of $\mathrm{Zn}$}

The apparent digestibility of Zn was determined using the method of Lu et al. [15]. $\mathrm{TiO}_{2}$ was added to all diets at $5 \mathrm{~g} / \mathrm{kg}$ as an external marker. At d18- $\mathrm{d} 21$, feces samples were harvested from each pigle, $t$ and then the feces were dried at $65{ }^{\circ} \mathrm{C}$ for $24 \mathrm{~h}$. The method of the concentrations of $\mathrm{TiO}_{2}$ and $\mathrm{Zn}$ in feces was described above. The apparent digestibility of $\mathrm{Zn}$ was calculated using the following formula.

Apparent digestibility of $\mathrm{Zn}(\%)=100 \times\left[\left(\mathrm{Zn} / \mathrm{TiO}_{2}\right)_{\text {feed }+ \text { water }}-\left(\mathrm{Zn} / \mathrm{TiO}_{2}\right)_{\mathrm{faces}}\right] /\left(\mathrm{Zn} / \mathrm{TiO}_{2}\right)_{\text {feed }+ \text { water }}$

\subsection{Activity of Zinc Containing Enzymes}

Zinc containing enzymes including total superoxide dismutase (T-SOD), alkaline phosphatase $(\mathrm{AKP})$, and $5^{\prime}$-nucleotidase $\left(5^{\prime}-\mathrm{NT}\right)$ were analyzed by using the commercially 
available kits (Nanjing Jiancheng Bioengineering Institute, Nanjing, China) according to the manufacturers' instructions. T-SOD, AKP and $5^{\prime}-\mathrm{NT}$ were determined separately at $550 \mathrm{~nm}, 520 \mathrm{~nm}$, and $680 \mathrm{~nm}$ with Multiscan Spectrum (Infinite M200 PRO, TECAN, CH).

\subsection{Real-Time Quantitative PCR Analysis}

The total RNA of liver, duodenum, jejunum, and ileum was extracted using Trizol reagent (Invitrogen, Carlsbad, CA, USA). The concentration of RNA was determined using a NanoDrop 2000 spectrophotometer (Thermo Scientific, Wilmington, DE, USA) and its integrity verified by electrophoresis on a $1 \%$ agarose gel. The cDNA was reverse transcribed from $1 \mu \mathrm{g}$ of total RNA using the Revert Aid Reverse Transcriptase (Takara, Japan), then used for evaluating gene expression. The primers used for target genes are presented in Table 2. The qPCR was performed in a $10-\mu \mathrm{L}$ reaction volume including $0.5 \mu \mathrm{M}$ of each forward and reverse primer, $2 \mu \mathrm{L}$ of cDNA, $2 \mu \mathrm{L}$ of DEPC treated water, and $5 \mu \mathrm{L}$ of SYBR Premix Ex Taq (Takara Bio Inc., Japan). The relative expression levels of genes were performed using the Lightcycler-480II system (Roche Diagnostics $\mathrm{GmbH}$, Mannheim, Germany). The PCR cycling condition was 40 cycles at $94{ }^{\circ} \mathrm{C}$ for $40 \mathrm{~s}, 60^{\circ} \mathrm{C}$ for $30 \mathrm{~s}$ and $72{ }^{\circ} \mathrm{C}$ for $35 \mathrm{~s}$. Zn-Met group served as the control group and $\mathrm{ZnSO}_{4}$, feed and $\mathrm{ZnSO}_{4}$, water groups served as treatment. The relative expression was expressed using the formula $2^{-(\Delta \Delta \mathrm{Ct})}$, where $\Delta \Delta \mathrm{Ct}=\left(\mathrm{Ct}_{\text {Target }}-\mathrm{Ct}_{\beta \text {-actin }}\right)_{\text {treatment }}-\left(\mathrm{Ct}_{\text {Target }}-\mathrm{Ct}_{\beta \text {-actin }}\right)_{\text {control }}[16,17]$. Relative expression was normalized and expressed as a ratio to the expression in the Zn-Met group.

Table 2. Primers used in this study.

\begin{tabular}{ccc}
\hline Gene & Accession No. & $\mathbf{5}^{\prime} \mathbf{- 3}^{\prime}$ Primer Sequence \\
\hline$\beta$-actin & XM_003357928 & F: CGTTGGCTGGTTGAGAATC \\
& R: CGGCAAGACAGAAATGACAA \\
ZIP4 & F: 021090449 & R: CGCTGAACTTGGCATCTGGG \\
& & F: CCAGGGGAGCAGGGAACCGA \\
ZnT1 & NM_001139470 & F: TCAGCCCGTTGGAGTTGCTGC \\
MT & NM_001001266.2 & R: CACAGAAAAAGGGATGTAGCATG \\
\hline
\end{tabular}

F, forward; R, Reverse; ZIP4, solute carrier family 39 member 4; ZnT1, zinc transporter 1; MT metallothionein.

\subsection{Western Blot Analysis}

Western blot analysis was done according to the method described by Yin et al. [18]. Protein extracts were prepared in RIPA Lysis Buffer (Beyotime Biotechnology Inc., Shanghai, China). Approximately $30 \mu \mathrm{g}$ proteins were subjected to SDS-PAGE electrophoresis. The duration of the electrophoresis was $30 \mathrm{~V}$ for $30 \mathrm{~min}, 80 \mathrm{~V}$ for $30 \mathrm{~min}$, and $120 \mathrm{~V}$ for 30 $\mathrm{min}$. Then, the proteins were transferred onto a PVDF membrane (Millipore, MA, USA) and blocked with 5\% non-fat milk in Tris-Tween buffered saline for $1.5 \mathrm{~h}$. Anti-Metallothionein rabbit polyclonal to antibody (ab233289, 1:5000, Abcam) and anti-beta actin mouse monoclonal antibody (60008-1, 1:5000, Proteintech) were used. The antibodies were incubated for $12 \mathrm{~h}$ at $4{ }^{\circ} \mathrm{C}$. After incubation with the HRP-conjugated secondary antibodies (ZB-2301, $1: 5000, \mathrm{ZSGB}$ ), the bands were visualized using the Alpha Imager 2200 software (Alpha Innotech Corporation, San Leandro, CA, USA).

\subsection{Statistical Analysis}

Data were analyzed by one-way analysis of variance followed by a Tukey's honestly significant difference test using SPSS (version 22) [19]. $p$ values of $<0.05$ were considered to indicate statistical significance among treatments. 


\section{Results}

3.1. Effect of Zinc Supplementation Forms on Growth Performance and Apparent Digestibility of Zn

The results for piglets' growth performance are presented in Table 3. The results show that there was no significant difference in growth performance between the groups with different $\mathrm{Zn}$ supplementation forms. The results showed that the $\mathrm{ZnSO}_{4}$, feed group had lower $(p<0.05)$ apparent digestibility of $\mathrm{Zn}$ in comparison with the $\mathrm{Zn}-\mathrm{Met}$ and $\mathrm{ZnSO}$, water groups. The results also showed that the $\mathrm{ZnSO}_{4}$, feed group had lower $(p<0.05)$ apparent digestibility of $\mathrm{Zn}$ compared with the Zn-Met and ZnSO4, water group.

Table 3. Effects of zinc supplementation forms on growth performance and apparent digestibility of $\mathrm{Zn}$ in piglets.

\begin{tabular}{ccccc}
\hline Items & Zn-Met & ZnSO $_{\text {, feed }}$ & ZnSO $_{4, \text { water }}$ & $p$-Value \\
\hline Average daily gain $(\mathrm{kg})$ & $0.443 \pm 0.0102$ & $0.471 \pm 0.0531$ & $0.435 \pm 0.0462$ & 0.209 \\
Average daily feed intake $(\mathrm{kg})$ & 0.730 & 0.730 & 0.730 & 1.000 \\
Final body weight $(\mathrm{kg})$ & $23.28 \pm 0.263$ & $23.90 \pm 0.432$ & $23.15 \pm 0.312$ & 0.274 \\
Feed: gain ratio & $1.67 \pm 0.0403$ & $1.56 \pm 0.0732$ & $1.69 \pm 0.0714$ & 0.265 \\
Apparent digestibility of $\mathrm{Zn}(\%)$ & $40.29 \pm 5.15^{\mathrm{a}}$ & $23.43 \pm 4.14^{\mathrm{b}}$ & $46.21 \pm 2.62^{\mathrm{a}}$ & 0.004 \\
\hline
\end{tabular}

$\overline{\mathrm{a}, \mathrm{b}}$ Values with different letters were significantly different $(p<0.05)$.

\subsection{Effect of Zinc Supplementation Forms on Tissue Mineral Concentrations}

The results are summarized in Table 4 . The $\mathrm{ZnSO}_{4}$, feed group showed a lower $(p<0.05)$ concentration of $\mathrm{Zn}$ in the piglets' liver and jejunum as compared to the $\mathrm{Zn}-\mathrm{Met}$ and $\mathrm{ZnSO}_{4}$, water groups. However, different $\mathrm{Zn}$ supplementation forms had no effect on $\mathrm{Cu}$ and $\mathrm{Fe}$ status in the piglets' liver, jejunum, and ileum.

Table 4. Effect of different $\mathrm{Zn}$ supplementation forms on mineral concentrations in the jejunum, ileum, and liver of the piglets.

\begin{tabular}{cccccc}
\hline Tissue & Items & Zn-Met & ZnSO $_{\text {,feed }}$ & ZnSO $_{\text {4,water }}$ & $p$-Value \\
\hline \multirow{3}{*}{ Liver } & $\mathrm{Zn}(\mathrm{mg} / \mathrm{kg})$ & $248.00 \pm 44.7^{\mathrm{a}}$ & $162.50 \pm 40.00^{\mathrm{b}}$ & $233.50 \pm 20.4^{\mathrm{a}}$ & 0.002 \\
& $\mathrm{Cu}(\mathrm{mg} / \mathrm{kg})$ & $16.72 \pm 2.64$ & $14.54 \pm 2.19$ & $13.48 \pm 3.08$ & 0.148 \\
& $\mathrm{Fe}(\mathrm{mg} / \mathrm{kg})$ & $111.10 \pm 20.8$ & $82.30 \pm 46.20$ & $87.90 \pm 21.0$ & 0.279 \\
\hline \multirow{3}{*}{ Jejunum } & $\mathrm{Zn}(\mathrm{mg} / \mathrm{kg})$ & $19.19 \pm 0.49^{\mathrm{a}}$ & $16.95 \pm 0.43^{\mathrm{b}}$ & $19.76 \pm 0.75^{\mathrm{a}}$ & 0.008 \\
& $\mathrm{Cu}(\mathrm{mg} / \mathrm{kg})$ & $1.86 \pm 0.21$ & $1.64 \pm 0.13$ & $1.74 \pm 0.08$ & 0.571 \\
& $\mathrm{Fe}(\mathrm{mg} / \mathrm{kg})$ & $55.06 \pm 5.52$ & $56.15 \pm 6.41$ & $38.78 \pm 2.81$ & 0.991 \\
\hline \multirow{3}{*}{ Ileum } & $\mathrm{Zn} \mathrm{(mg/kg)}$ & $15.07 \pm 0.54$ & $17.03 \pm 0.57$ & $16.87 \pm 0.73$ & 0.075 \\
& $\mathrm{Cu}(\mathrm{mg} / \mathrm{kg})$ & $1.33 \pm 0.26$ & $1.32 \pm 0.20$ & $0.90 \pm 0.23$ & 0.336 \\
& $\mathrm{Fe}(\mathrm{mg} / \mathrm{kg})$ & $8.40 \pm 0.70$ & $8.84 \pm 0.95$ & $7.79 \pm 0.39$ & 0.595 \\
\hline
\end{tabular}

Means in the same row with different letters were significantly different among groups $(p<0.05)$.

3.3. Effect of Zn Supplementation Forms on Zn-Containing Enzymes in Duodenum, Jejunum, Ileum and Liver

As presented in Table 5, the $\mathrm{ZnSO}_{4}$, feed group had lower $(p<0.05)$ jejunal AKP activity in comparison with the $\mathrm{Zn}$-Met group. Furthermore, the T-SOD activity in the ileum was lower $(p<0.05)$ in the $\mathrm{ZnSO}_{4}$, feed group as compared to the $\mathrm{Zn}-$ Met and $\mathrm{ZnSO}_{4}$, water groups. 
Table 5. Effect of different Zn supplementation forms on Zn-containing enzymes in the duodenum, jejunum, ileum, and liver of the piglets.

\begin{tabular}{cccccc}
\hline Tissue & Item & Zn-Met & ZnSO $_{4 \text {,feed }}$ & ZnSO $_{4 \text {,water }}$ & $p$-Value \\
\hline \multirow{5}{*}{ Duodenum } & T-SOD & $52.16 \pm 4.74$ & $58.00 \pm 7.77$ & $55.37 \pm 4.60$ & 0.785 \\
& AKP & $15.22 \pm 1.92$ & $15.63 \pm 2.31$ & $19.49 \pm 1.66$ & 0.273 \\
& $5^{\prime}$-NT & $10.85 \pm 1.19$ & $8.19 \pm 0.75$ & $9.47 \pm 1.06$ & 0.216 \\
\hline \multirow{3}{*}{ Jejunum } & T-SOD & $72.67 \pm 4.81$ & $64.89 \pm 3.80$ & $82.82 \pm 7.96$ & 0.124 \\
& AKP & $39.17 \pm 2.64^{\mathrm{a}}$ & $29.85 \pm 1.60^{\mathrm{b}}$ & $36.35 \pm 30.06^{\mathrm{ab}}$ & 0.031 \\
& $5^{\prime}$-NT & $15.81 \pm 1.38$ & $12.24 \pm 1.03$ & $17.71 \pm 2.51$ & 0.116 \\
\hline \multirow{3}{*}{ Ileum } & T-SOD & $68.73 \pm 4.1^{\mathrm{a}}$ & $54.26 \pm 2.38^{\mathrm{b}}$ & $66.11 \pm 4.62^{\mathrm{a}}$ & 0.039 \\
& AKP & $34.85 \pm 1.70$ & $31.02 \pm 1.89$ & $36.13 \pm 3.95$ & 0.406 \\
& $5^{\prime}$-NT & $15.95 \pm 1.40$ & $16.36 \pm 1.67$ & $15.11 \pm 1.08$ & 0.815 \\
\hline \multirow{3}{*}{ liver } & T-SOD & $176.34 \pm 72.06$ & $232.20 \pm 32.12$ & $195.37 \pm 32.34$ & 0.478 \\
& AKP & $32.20 \pm 12.00$ & $37.64 \pm 10.78$ & $16.48 \pm 5.78$ & 0.317 \\
& $5^{\prime}$-NT & $34.49 \pm 7.95$ & $45.97 \pm 5.57$ & $45.68 \pm 8.79$ & 0.503 \\
\hline
\end{tabular}

Means in the same row with different letters were significantly different among groups $(p<0.05)$.

3.4. Effect of Zn Supplementation Forms on MT mRNA and Protein Expressions in the Duodenum, Jejunum, Ileum and Liver

Figures 1 and 2 showed that the mRNA expression and protein abundance of MT in the jejunum of the $\mathrm{Zn}$-Met group and $\mathrm{ZnSO}_{4}$, water group piglets were higher than those in piglets from $\mathrm{ZnSO}_{4}$, feed group $(p<0.05)$. In addition, the $\mathrm{ZnSO}_{4}$, feed group significantly decreased the expression of MT in the ileum in comparison with the Zn-Met group $(p<0.05)$. Meanwhile, supplementation of $\mathrm{ZnSO} 4$ in drinking water increased the MT mRNA expression and protein abundance in the liver as compared to the Zn-Met and $\mathrm{ZnSO}_{4}$, feed groups $(p<0.05)$. However, there was no significant difference in MT mRNA expression and protein abundance in the duodenum between groups.
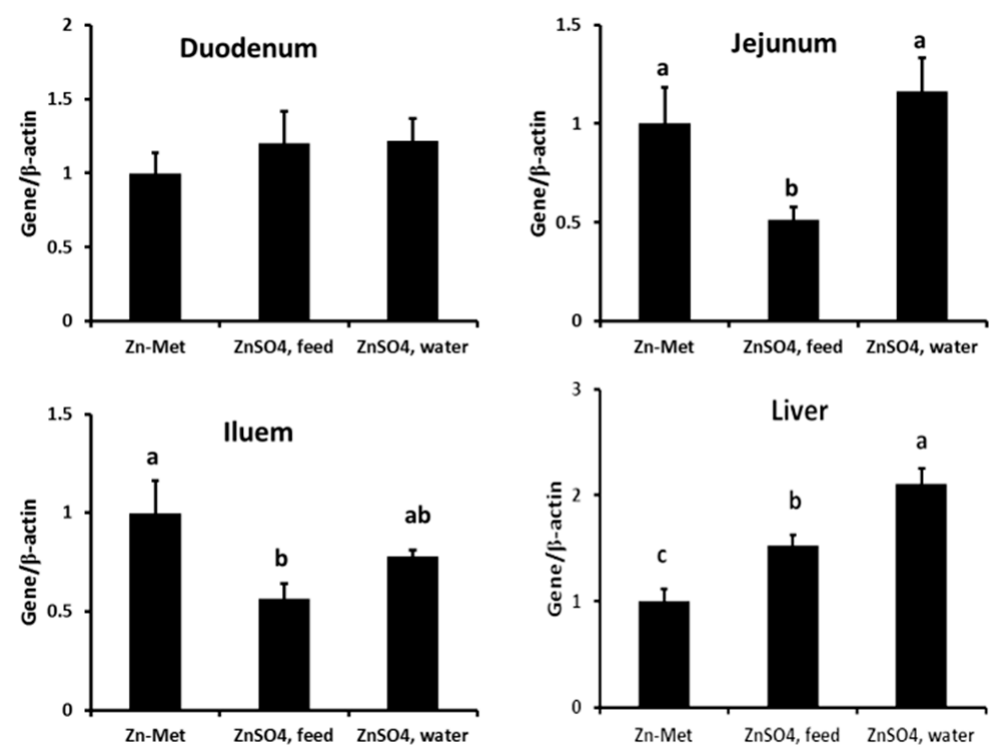

Figure 1. Effect of different Zn supplementation forms on MT mRNA expression in the duodenum, jejunum, ileum, and liver of the piglets. a-c: different letters were significantly different among groups $(p<0.05)$. 

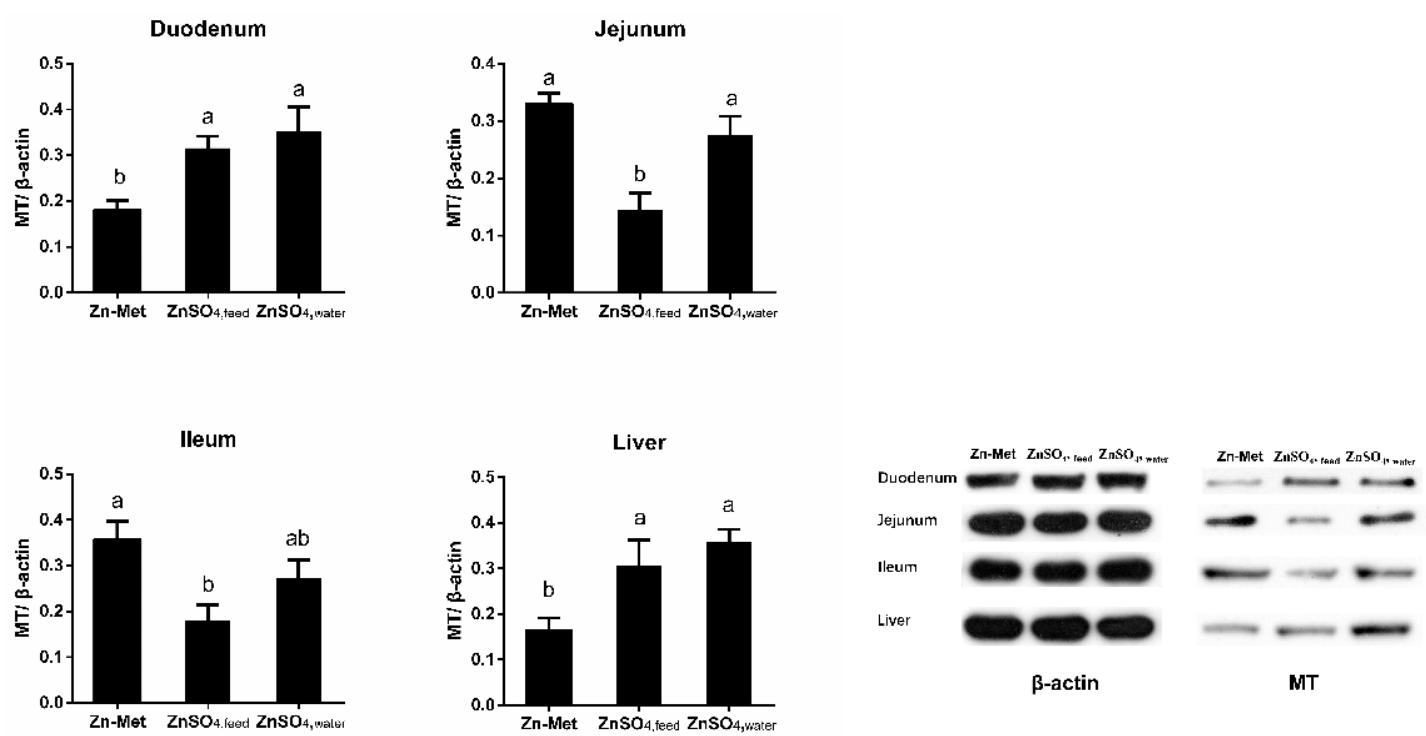

Figure 2. Effect of different Zn supplementation forms on MT protein levels in the duodenum, jejunum, ileum, and liver of the piglets. $\mathrm{a}, \mathrm{b}$ : different letters were significantly different among groups $(p<0.05)$.

3.5. Effect of Zn Supplementation Forms on ZIP4 and ZnT1 mRNA Expressions in Duodenum and Jejunum

As presented in Figure 3, no significant difference was observed in ZIP4 and ZnT1 mRNA expressions in duodenum and jejunum between groups with different $\mathrm{Zn}$ supplementation forms.

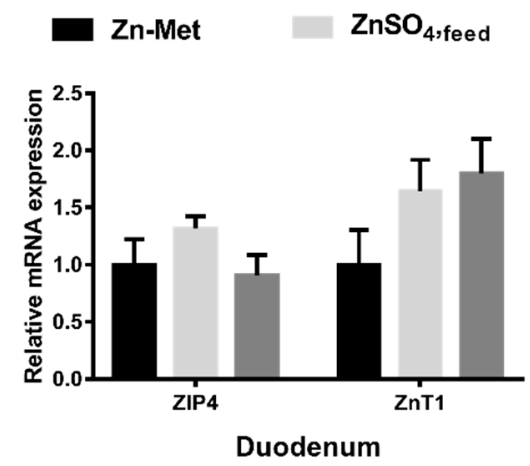

$\mathrm{ZnSO}_{4}$,water

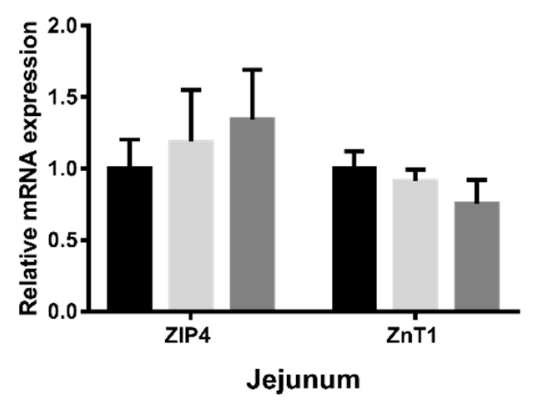

Figure 3. Effect of different Zn supplementation forms on ZIP4 and ZnT1 mRNA expressions in the duodenum and jejunum of piglets.

\section{Discussion}

The present study showed that the different $\mathrm{Zn}$ supplementation forms had no effect on the growth performance of piglets. Xie et al. [9] also reported that there was no significant difference in the growth performance of pigs fed diets supplemented with different levels or sources of $\mathrm{Zn}$. A recent study by Zhang et al. found that the piglets fed with 20, 40, and $80 \mathrm{mg} \mathrm{Zn/kg}$ as zinc amino acid complex had a similar growth performance to pigs fed with $40 \mathrm{mg} \mathrm{Zn/kg} \mathrm{as} \mathrm{ZnSO}_{4}$. Mallaki et al. [20] observed a higher average daily gain and lower feed conversion ratio in male lambs supplemented with $\mathrm{Zn}$-peptide as compared to those fed $\mathrm{ZnSO}_{4}$. Therefore, the addition of $150 \mathrm{mg} / \mathrm{kg}$ of $\mathrm{Zn}$ in piglets' diets might be an adequate level for the growth of pigs from $15 \mathrm{~kg}$ to $24 \mathrm{~kg}$ body weight. Another possible explanation might the shorter intervention time of the $\mathrm{Zn}$ supplementation and the smaller sample size of the experiment. However, growth performance parameters may not be an ideal index to evaluate $\mathrm{Zn}$ requirements, tissue $\mathrm{Zn}$ 
concentration and $\mathrm{Zn}$-dependent enzyme activities are considered as sensitive criteria to determine the requirements.

Although $\mathrm{Zn}$ supplementation form had no effect on the growth performance of piglets, there is still a question whether it can influence the bioavailability of $\mathrm{Zn}$ in pigs or not. Phytates are identified as the limiting factor of $\mathrm{Zn}$ absorption in monogastrics by forming insoluble phytate- $\mathrm{Zn}$ complexes. The concentration of feed phytate is approximately $0.8 \sim 2.5 \mathrm{~g} / \mathrm{kg}$ [21]. Zn-Met, organic metal chelates composed of Zn chelated with Met in coordinate covalent bonds, chelate is stable in the small intestine, may minimize the formation of $\mathrm{Zn}$-phytate complex and allow more $\mathrm{Zn}$ to be absorbed by the epithelial cells in the small intestine [22]. In contrast, inorganic form, $\mathrm{ZnSO}_{4}$, is easily dissociated in the stomach and intestine, therefore, Zn-phytate complex is formed, rendering a lower absorption of Zn [23]. The current study demonstrated that $\mathrm{Zn}$-Met added in feed improved $\mathrm{Zn}$ apparent digestibility. This is in agreement with previous studies, in which organic $\mathrm{Zn}$ sources such as Zn-Met, Zn-proteinate and Zn-glycinate had a greater bioavailability as compared to inorganic $\mathrm{Zn}$ forms [23-25]. Moreover, this study found that $\mathrm{ZnSO}_{4}$ dissolved in drinking water also had higher $\mathrm{Zn}$ apparent digestibility in comparison with $\mathrm{ZnSO}_{4}$ added in feed. That might be because piglets did not drink $\mathrm{ZnSO}_{4}$ dissolved in water at feeding time, which reduced the contact of $\mathrm{Zn}^{2+}$ with phytic acid in the feed.

Zinc from different sources was found to be digested and absorbed in the intestine, where intestinal MT captured a small part of the absorbed $\mathrm{Zn}$, and the remaining major part is captured by hepatic MT [26]. Thus, intestinal and liver Zn contents can accurately reflect the differences in $\mathrm{Zn}$ absorption and utilization from different $\mathrm{Zn}$ sources. In the present study, the results showed that supplementation of Zn-Met added in feed and $\mathrm{ZnSO}_{4}$ dissolved in drinking water significantly enhanced $\mathrm{Zn}$ contents in the liver and jejunum of piglets. This is in agreement with a previous study by Liu et al. [27], in which the supplementation of organic $\mathrm{Zn}$ to growing-finishing pigs significantly increased the concentrations of $\mathrm{Zn}$ in the liver in comparison with the inorganic $\mathrm{Zn}$ supplementation. The results indicated that $\mathrm{ZnSO}_{4}$ dissolved in drinking water was better absorbed and utilized than $\mathrm{ZnSO} 4$ added in feed. Meanwhile, $\mathrm{Zn}$ supplementation forms had no effect on $\mathrm{Cu}$ and $\mathrm{Fe}$ contents in the liver, jejunum, and ileum. Therefore, the results suggest that $\mathrm{Zn}$-Met added in feed and $\mathrm{ZnSO}_{4}$ dissolved in drinking water improved $\mathrm{Zn}$ absorption and had no effect on $\mathrm{Cu}$ and $\mathrm{Fe}$ absorption.

$\mathrm{Zn}$ is an important ingredient in zinc-containing metalloenzymes, including T-SOD, AKP, and $5^{\prime}-\mathrm{NT}$. Previous studies showed that T-SOD, AKP, and $5^{\prime}-\mathrm{NT}$ activities were significantly affected by $\mathrm{Zn}$ deposition and can be used for the evaluation of body $\mathrm{Zn}$ status [28]. Several studies have shown that T-SOD, AKP, and 5'-NT levels were affected by different Zn supplementation forms [29,30]. Our current study showed that Zn-Met added in feed and $\mathrm{ZnSO}_{4}$ dissolved in drinking water could increase the activities of AKP in the jejunum and T-SOD in the ileum as compared to the $\mathrm{ZnSO}_{4}$ added in feed. Li et al. [30] found that pigs fed a basal diet supplemented with 40, 60, 80, and $100 \mathrm{mg} / \mathrm{kg}$ of $\mathrm{Zn}$ as ZnMet increased the AKP activity in serum as compared to the pigs who were fed a basal diet supplemented with $80 \mathrm{mg}$ of $\mathrm{Zn} / \mathrm{kg}$ as $\mathrm{ZnSO}_{4}$. Thus, the present study results supported the hypothesis that the increase of AKP and T-SOD activities might result from higher $\mathrm{Zn}$ availability in the body. Moreover, $\mathrm{Zn}$-Met added in feed and $\mathrm{ZnSO}_{4}$ dissolved in drinking water might supply more available $\mathrm{Zn}$ for enzymes to maintain their normal activity.

The increased $\mathrm{Zn}$ concentrations and $\mathrm{Zn}$-containing enzymes activities in the jejunum and liver resulting from the supplementation of $\mathrm{Zn}$-Met added in feed and $\mathrm{ZnSO}_{4}$ dissolved in drinking water that were observed in present study may be associated with $\mathrm{Zn}$ absorption and transportation [31]. MT and zinc transporters (ZnT and ZIP families) are the proteins involved in intracellular zinc homeostasis through influxing, chelating, sequestrating, coordinating, releasing, and effluxing Zn. MT is a group of low-molecular-weight metal-binding proteins that bind zinc with high affinity and to serve as an intracellular zinc reservoir [32]. MT expression is induced by zinc elevation, and thus, zinc homeostasis is maintained [26,32]. The small intestine is the primary site for $\mathrm{Zn}$ absorption. Hence, 
the increasing amounts of MT in the small intestine indicate that $\mathrm{Zn}$ was more available for absorption by the animal. The present study showed that Zn-Met added in feed and $\mathrm{ZnSO}_{4}$ dissolved in drinking water could increase the mRNA expression of MT and protein abundance in jejunum and ileum in comparison with the $\mathrm{ZnSO}_{4}$ added in fed. In a previous study, the addition of different $Z$ n sources has been found to increase the mRNA expressions of MT in intestinal porcine epithelial cells [33]. Moreover, Huang et al. also found that the increased levels of dietary Zn-glycine supplementation significantly enhanced the expression of MT1 mRNA in the duodenum [34], which may suggest that Zn-Met added in feed and $\mathrm{ZnSO}_{4}$ dissolved in drinking water improved the $\mathrm{Zn}$ availability in comparison with $\mathrm{ZnSO}_{4}$ added in the fed. Another possible reason might be explained as $\mathrm{Zn}$-Met added in feed and $\mathrm{ZnSO}_{4}$ dissolved in drinking water could stimulate $\mathrm{Zn}$ absorption capacity compared to the $\mathrm{ZnSO}_{4}$ added in fed. The hepatic MT bound to majority of $\mathrm{Zn}$ in the liver, MT concentrations in the liver was found positively associated with the Zn concentration in pigs [35].

ZIP and ZnT transporter family proteins which transport $\mathrm{Zn}^{2+}$ across biological membranes play crucial role in maintaining $\mathrm{Zn}$ homeostasis [36]. ZIP4 is essential for Zn accumulation from the gut lumen, locates at the apical membrane of enterocytes. The level of ZIP4 mRNA expression in the intestine can be upregulated under Zn deficiency and downregulated under increased Zn concentration [37]. In contrast, intestinal ZnT1 transport cytosolic $\mathrm{Zn}^{2+}$ into the circulation [38]. Previous study also has shown that different Zn supplementation form affect Zn absorption, when dietary Zn increases, absorption of $\mathrm{Zn}$ decreases [39]. The present study found that different that $\mathrm{Zn}$ supplementation form had no effect on the mRNA expressions of ZIP4 and ZnT1 in the duodenum and jejunum of pigs. It may be resulted from different $\mathrm{Zn}$ supplement patterns contain the same does of $\mathrm{Zn}$ that did not have much effect on the transcription of ZIP4 and ZnT1.

\section{Conclusions}

In summary, $\mathrm{Zn}$-Met added in feed and $\mathrm{ZnSO}_{4}$ dissolved in drinking water was more effective for $\mathrm{Zn}$ accumulation in the jejunum and for enzyme activities in the jejunum and ileum. These results are also supported by the mRNA expression and protein abundance of MT in jejunum and ileum. However, different Zn supplement patterns did not have much effect on the transcription of ZIP4 and ZnT1 in the duodenum and jejunum of pigs. The concrete mechanism of $\mathrm{Zn}$-Met added in feed and $\mathrm{ZnSO}_{4}$ dissolved in drinking water needs to be further studied.

Supplementary Materials: The following are available online at https:/ / www.mdpi.com/2076-261 5/11/1/36/s1, Table S1. Daily feed intake and $\mathrm{ZnSO}_{4}$ in drinking water intake.

Author Contributions: H.-J.N., F.-F.L. and M.A.K.A. designed the research; F.-F.L., Z.-H.L., J.L. and K.-B.M. conducted research and animal experiment; H.-J.N., F.-F.L., M.A.K.A. and Z.-H.L. analyzed the data and wrote the paper; H.-J.N., F.-F.L., M.A.K.A. and Z.-H.L. had primary responsibility for final content. All authors read and approved the final manuscript.

Funding: This research was funded by the Open Research Fund of Hunan Provincial Key Laboratory of Animal Nutritional Physiology and Metabolic Process (No. ISA2020211), Special Funds for Construction of Innovative Provinces in Hunan Province (No. 2019RS3022), Basic and Applied Basic Research Fund of Guangdong Province (No. 2019B1515210022).

Institutional Review Board Statement: The study was conducted according to the guidelines of the Declaration of Helsinki, and approved by the Institutional Review Board (or Ethics Committee) of Animal Care and Use Committee of the Institute of Subtropical Agriculture, Chinese Academy of Sciences ((IACUC \# 201302).

Informed Consent Statement: Informed consent was obtained from all subjects involved in the study.

Data Availability Statement: All data used in the current study are available from the corresponding author on reasonable request.

Conflicts of Interest: The authors declare no conflict of interest. 


\section{References}

1. Livingstone, C. Zinc: Physiology, deficiency, and parenteral nutrition. Nutr. Clin. Pract. 2015, 30, 371-382. [CrossRef]

2. Brugger, D.; Windisch, W.M. Short-Term Subclinical Zinc Deficiency in Weaned Piglets Affects Cardiac Redox Metabolism and Zinc Concentration. J. Nutr. 2017, 147, 521-527. [CrossRef]

3. Mocchegiani, E.; Romeo, J.; Malavolta, M.; Costarelli, L.; Giacconi, R.; Diaz, L.E.; Marcos, A. Zinc: Dietary intake and impact of supplementation on immune function in elderly. Age (Dordr.) 2013, 35, 839-860. [CrossRef]

4. Brugger, D.; Windisch, W.M. Subclinical zinc deficiency impairs pancreatic digestive enzyme activity and digestive capacity of weaned piglets. Br. J. Nutr. 2016, 116, 425-433. [CrossRef]

5. Pieper, R.; Martin, L.; Schunter, N.; Villodre Tudela, C.; Weise, C.; Klopfleisch, R.; Zentek, J.; Einspanier, R.; Bondzio, A. Impact of high dietary zinc on zinc accumulation, enzyme activity and proteomic profiles in the pancreas of piglets. J. Trace Elem. Med. Biol. 2015, 30, 30-36. [CrossRef]

6. Peng, Z.; Zhang, J.; Fanning, S.; Wang, L.; Li, M.; Maheshwari, N.; Sun, J.; Li, F. Effects of metal and metalloid pollutants on the microbiota composition of feces obtained from twelve commercial pig farms across China. Sci. Total Environ. 2019, 647, 577-586. [CrossRef] [PubMed]

7. Zhang, Y.; Ward, T.L.; Ji, F.; Peng, C.; Zhu, L.; Gong, L.; Dong, B. Effects of zinc sources and levels of zinc amino acid complex on growth performance, hematological and biochemical parameters in weanling pigs. Asian Australas. J. Anim. Sci. 2018, 31, 1267-1274. [CrossRef] [PubMed]

8. Olukosi, O.A.; van Kuijk, S.; Han, Y. Copper and zinc sources and levels of zinc inclusion influence growth performance, tissue trace mineral content, and carcass yield of broiler chickens. Poult. Sci. 2018, 97, 3891-3898. [CrossRef] [PubMed]

9. Xie, Y.; Zhang, Q.; Wang, L.; Wang, Y.; Cheng, Z.; Yang, Z.; Yang, W. The Effects of Partially or Completely Substituted Dietary Zinc Sulfate by Lower Levels of Zinc Methionine on Growth Performance, Apparent Total Tract Digestibility, Immune Function, and Visceral Indices in Weaned Piglets. Animals (Basel) 2019, 9, 236. [CrossRef] [PubMed]

10. Li, L.; Li, H.; Zhou, W.; Feng, J.; Zou, X. Effects of zinc methionine supplementation on laying performance, zinc status, intestinal morphology, and expressions of zinc transporters' mRNA in laying hens. J. Sci. Food Agric. 2019, 99, 6582-6588. [CrossRef]

11. Kaewtapee, C.; Krutthai, N.; Poosuwan, K.; Poeikhampha, T.; Koonawootrittriron, S.; Bunchasak, C. Effects of adding liquid DL-methionine hydroxy analogue-free acid to drinking water on growth performance and small intestinal morphology of nursery pigs. J. Anim. Physiol. Anim. Nutr. (Berl.) 2010, 94, 395-404. [CrossRef] [PubMed]

12. AOAC. Official Methods of Analysis, 18th ed; AOAC International: Gaithersburg, MD, USA, 2005.

13. Bai, M.; Liu, H.; Xu, K.; Yu, R.; Oso, A.O.; Deng, J.; Yin, Y. Effects of coated cysteamine hydrochloride on muscle fiber characteristics and amino acid composition of finishing pigs. Asian Australas. J. Anim. Sci. 2019, 32, 1430-1438. [CrossRef] [PubMed]

14. Cheng, Y.F.; Chen, Y.P.; Li, X.H.; Yang, W.L.; Wen, C.; Zhou, Y.M. Effects of Palygorskite Inclusion on the Growth Performance, Meat Quality, Antioxidant Ability, and Mineral Element Content of Broilers. Biol. Trace Elem. Res. 2016, 173, 194-201. [CrossRef] [PubMed]

15. Lu, H.; Shin, S.; Kuehn, I.; Bedford, M.; Rodehutscord, M.; Adeola, O.; Ajuwon, K.M. Effect of phytase on nutrient digestibility and expression of intestinal tight junction and nutrient transporter genes in pigs. J. Anim. Sci. 2020, 98. [CrossRef]

16. Stämmler, F.; Gläsner, J.; Hiergeist, A.; Holler, E.; Weber, D.; Oefner, P.J.; Gessner, A.; Spang, R. Adjusting microbiome profiles for differences in microbial load by spike-in bacteria. Microbiome 2016, 4, 28. [CrossRef] [PubMed]

17. Falcone, E.L.; Abusleme, L.; Swamydas, M.; Lionakis, M.S.; Ding, L.; Hsu, A.P.; Zelazny, A.M.; Moutsopoulos, N.M.; Kuhns, D.B.; Deming, C.; et al. Colitis susceptibility in p47(phox-/-) mice is mediated by the microbiome. Microbiome 2016, 4, 13. [CrossRef]

18. Yin, J.; Li, Y.; Zhu, X.; Han, H.; Ren, W.; Chen, S.; Bin, P.; Liu, G.; Huang, X.; Fang, R.; et al. Effects of Long-Term Protein Restriction on Meat Quality, Muscle Amino Acids, and Amino Acid Transporters in Pigs. J. Agric. food Chem. 2017, 65, 9297-9304. [CrossRef]

19. Stewart, C.J.; Embleton, N.D.; Marrs, E.C.; Smith, D.P.; Nelson, A.; Abdulkadir, B.; Skeath, T.; Petrosino, J.F.; Perry, J.D.; Berrington, J.E.; et al. Temporal bacterial and metabolic development of the preterm gut reveals specific signatures in health and disease. Microbiome 2016, 4, 67. [CrossRef]

20. Mallaki, M.; Norouzian, M.A.; Khadem, A.A. Effect of organic zinc supplementation on growth, nutrient utilization, and plasma zinc status in lambs. Turk. J. Vet. Anim. Sci. 2015, 39, 75-80. [CrossRef]

21. Schlegel, P.; Sauvant, D.; Jondreville, C. Bioavailability of zinc sources and their interaction with phytates in broilers and piglets. Animal 2013, 7, 47-59. [CrossRef]

22. Behjatian Esfahani, M.; Moravej, H.; Ghaffarzadeh, M.; Nehzati Paghaleh, G.A. Comparison the Zn-Threonine, Zn-Methionine, and Zn Oxide on Performance, Egg Quality, Zn Bioavailability, and Zn Content in Egg and Excreta of Laying Hens. Biol. Trace Elem. Res. 2020. [CrossRef]

23. Ren, P.; Chen, J.; Wedekind, K.; Hancock, D.; Vázquez-Añón, M. Interactive effects of zinc and copper sources and phytase on growth performance, mineral digestibility, bone mineral concentrations, oxidative status, and gut morphology in nursery pigs. Transl. Anim. Sci. 2020, 4, txaa083. [CrossRef] [PubMed]

24. Suo, H.; Lu, L.; Zhang, L.; Zhang, X.; Li, H.; Lu, Y.; Luo, X. Relative bioavailability of zinc-methionine chelate for broilers fed a conventional corn-soybean meal diet. Biol. Trace Elem. Res. 2015, 165, 206-213. [CrossRef] [PubMed]

25. Schlegel, P.; Windisch, W. Bioavailability of zinc glycinate in comparison with zinc sulphate in the presence of dietary phytate in an animal model with Zn labelled rats. J. Anim. Physiol. Anim. Nutr. (Berl.) 2006, 90, 216-222. [CrossRef]

26. Grungreiff, K.; Reinhold, D.; Wedemeyer, H. The role of zinc in liver cirrhosis. Ann. Hepatol. 2016, 15, 7-16. [CrossRef] 
27. Liu, B.; Xiong, P.; Chen, N.; He, J.; Lin, G.; Xue, Y.; Li, W.; Yu, D. Effects of Replacing of Inorganic Trace Minerals by Organically Bound Trace Minerals on Growth Performance, Tissue Mineral Status, and Fecal Mineral Excretion in Commercial Grower-Finisher Pigs. Biol. Trace Elem. Res. 2016, 173, 316-324. [CrossRef]

28. Min, Y.N.; Liu, F.X.; Qi, X.; Ji, S.; Ma, S.X.; Liu, X.; Wang, Z.P.; Gao, Y.P. Effects of methionine hydroxyl analog chelated zinc on laying performance, eggshell quality, eggshell mineral deposition, and activities of Zn-containing enzymes in aged laying hens. Poult. Sci. 2018, 97, 3587-3593. [CrossRef]

29. Yang, W.; Chen, Y.; Cheng, Y.; Wen, C.; Zhou, Y. Effects of zinc bearing palygorskite supplementation on the growth performance, hepatic mineral content, and antioxidant status of broilers at early age. Asian Australas. J. Anim. Sci. 2017, 30, 1006-1012. [CrossRef]

30. Li, L.L.; Gong, Y.J.; Zhan, H.Q.; Zheng, Y.X.; Zou, X.T. Effects of dietary Zn-methionine supplementation on the laying performance, egg quality, antioxidant capacity, and serum parameters of laying hens. Poult. Sci. 2019, 98, 923-931. [CrossRef]

31. Swain, P.S.; Rao, S.B.N.; Rajendran, D.; Pal, D.; Mondal, S.; Selvaraju, S. Effect of Supplementation of Nano Zinc Oxide on Nutrient Retention, Organ and Serum Minerals Profile, and Hepatic Metallothionein Gene Expression in Wister Albino Rats. Biol. Trace Elem. Res. 2019, 190, 76-86. [CrossRef]

32. Baltaci, A.K.; Yuce, K.; Mogulkoc, R. Zinc Metabolism and Metallothioneins. Biol. Trace Elem. Res. 2018, 183, $22-31$. [CrossRef] [PubMed]

33. Huang, D.; Zhuo, Z.; Fang, S.; Yue, M.; Feng, J. Different Zinc Sources Have Diverse Impacts on Gene Expression of Zinc Absorption Related Transporters in Intestinal Porcine Epithelial Cells. Biol. Trace Elem. Res. 2016, 173, 325-332. [CrossRef] [PubMed]

34. Huang, D.; Hu, Q.; Fang, S.; Feng, J. Dosage Effect of Zinc Glycine Chelate on Zinc Metabolism and Gene Expression of Zinc Transporter in Intestinal Segments on Rat. Biol. Trace Elem. Res. 2016, 171, 363-370. [CrossRef] [PubMed]

35. Zetzsche, A.; Schunter, N.; Zentek, J.; Pieper, R. Accumulation of copper in the kidney of pigs fed high dietary zinc is due to metallothionein expression with minor effects on genes involved in copper metabolism. J. Trace Elem. Med. Biol. 2016, 35, 1-6. [CrossRef] [PubMed]

36. Kambe, T.; Tsuji, T.; Hashimoto, A.; Itsumura, N. The Physiological, Biochemical, and Molecular Roles of Zinc Transporters in Zinc Homeostasis and Metabolism. Physiol. Rev. 2015, 95, 749-784. [CrossRef] [PubMed]

37. Karweina, D.; Kreuzer-Redmer, S.; Muller, U.; Franken, T.; Pieper, R.; Baron, U.; Olek, S.; Zentek, J.; Brockmann, G.A. The Zinc Concentration in the Diet and the Length of the Feeding Period Affect the Methylation Status of the ZIP4 Zinc Transporter Gene in Piglets. PLoS ONE 2015, 10, e0143098. [CrossRef]

38. Brugger, D.; Windisch, W.M. Zn metabolism of monogastric species and consequences for the definition of feeding requirements and the estimation of feed Zn bioavailability. J. Zhejiang Univ. Sci. B 2019, 20, 617-627. [CrossRef]

39. VanValin, K.R.; Genther-Schroeder, O.N.; Carmichael, R.N.; Blank, C.P.; Deters, E.L.; Hartman, S.J.; Niedermayer, E.K.; Laudert, S.B.; Hansen, S.L. Influence of dietary zinc concentration and supplemental zinc source on nutrient digestibility, zinc absorption, and retention in sheep. J. Anim. Sci. 2018, 96, 5336-5344. [CrossRef] 